\title{
Is metabolic syndrome related to postmenopausal osteoporosis? retrospective study
}

\section{Metabolik sendrom postmenopozal osteoporoz ile ilişkili midir? Retrospektif bir çalışma}

\author{
Elif Turan ${ }^{1}$, Hafize Kızılkaya ${ }^{2}$, Yalçın Aral ${ }^{1}$
}

\begin{abstract}
Aim: To evaluate the difference between postmenopausal women with and without osteoporosis in terms of metabolic syndrome.

Methods: A total of 98 postmenopausal women younger than 65 years, were enrolled in the study. According to the bone mineral density examination; 49 participants who had T-score $>-2.5$ at the spine or/and femoral neck were included in the group without osteoporosis (Group 1), and 49 participants who had T-score $\leq-2.5$ at the spine or/and femoral neck were included in the osteoporosis group (Group 2). Patient's profile which included all demographic data, particularly anthropometric evaluation and medical history was obtained. Serum fasting glucose, lipid profiles and $25 \mathrm{OH}$ vitamin $\mathrm{D}$ levels were also recorded.

Results: Age $(\mathrm{p}=0.001)$, menopausal age $(\mathrm{p}=0.003)$, systolic blood pressure $(\mathrm{p}=0.004)$ and diastolic blood pressure $(\mathrm{p}=0.001)$ of Group 2 were significantly higher than Group 1 . There were no significant difference in terms of body mass index, weight, lipid profiles, serum calcium and serum $25 \mathrm{OH}$ vitamin D levels among the groups ( $>0.05$ for all). Twenty five (51\%) of 49 women in Group 1 and $36(73 \%)$ of 49 women in Group 2 had metabolic syndrome. There was a statistically significant relationship between osteoporosis and the metabolic
\end{abstract} syndrome $(\mathrm{p}=0.037)$.

Conclusion: Our results demonstrated that osteoporosis is related with the metabolic syndrome in postmenopausal women.

Keywords: Metabolic syndrome, menopause, osteoporosis

Öz

Amaç: Postmenopozal kadınlarda, osteoporoz ile metabolik sendrom arasındaki ilişkiyi değerlendirmek.

Yöntemler: 65 yaşın altında toplam 98 postmenopozal kadın çalışmaya dahil edildi. Kemik mineral dansitometre sonucuna göre; lumber ve/veya femur boyun T skoru>-2.5 olan 49 hasta postmenopozal osteoporoz olmayan gruba (Grup 1), T skoru $\leq-2.5$ olan 49 hasta postmenopozal osteoporoz grubuna (Grup 2) dahil edildi. Tüm demografik verileri içeren hasta profili, antropometrik değerlendirme ve tıbbi öykü kaydedildi. Serum açlık glukozu, lipit profili ve serum $25 \mathrm{OH}$ D vitamin seviyesi de kaydedildi.

Bulgular: Grup 1 ve Grup 2 karşılaştırıldığında; yaş $(\mathrm{p}=0.001)$, menopoz yaşı $(\mathrm{p}=0.003)$ sistolik kan basıncı $(\mathrm{p}=0.004)$ ve diyastolik kan basıncı $(\mathrm{p}=0.001)$ Grup 2 'de Grup 1'e göre anlamlı șekilde daha yüksekti. Vücu kitle indeksi, boy, kilo, lipid profili, serum $25 \mathrm{OH}$ vitamin D düzeyleri açısından gruplar arasında anlamlı fark yoktu ( $p>0.05$ ). Osteoporozu olan 49 hastanın 36'sinda (\%73), osteoporozu olmayan 49 hastanın ise 25 'inde (\%51) metabolik sendrom tespit edildi. Osteoporoz ile metabolik sendrom arasında istatistiksel olarak anlaml ilișki tespit edildi ( $\mathrm{p}=0.037)$.

Sonuç: Postmenopozal kadınlarda osteoporoz ile metabolik sendrom arasında anlamlı ilişki olduğu tespit edilmiştir.

Anahtar Kelimeler: Metabolik sendrom, menopoz, osteoporoz.
${ }^{1}$ Department of Endocrinology and Metabolic Disease, Medical School of Bozok University, Yozgat, Turkey.

${ }^{2}$ Department of Internal Medicine, Medical School of Bozok University, Yozgat, Turkey.

Ethics Committee Approval: The study wass approved by the local ethical authority.

Etik Kurul Onayı: Çalışma lokal etik komite tarafindan onaylanmıștır.

Conflict of Interest: No conflict of interest was declared by the authors.

Çıkar Çatışması: Yazarlar çıkar çatışması bildirmemişlerdir.

Financial Disclosure: The authors declared that this study has received no financial support.

Finansal Destek: Yazarlar bu çalıșma için finansal destek almadıklarını beyan etmişlerdir.

Geliş Tarihi / Received: 30.04 .2018

Kabul Tarihi / Accepted: 30.06 .2018

Yayın Tarihi / Published: 20.07.2018

Sorumlu yazar / Corresponding author:

Elif Turan

Bozok University, Medical School, Dept of Endocrinology, 66040 Yozgat / Turkey

Phone: +9003542127050

e-mail: drelifturan@hotmail.com

Copyright $\odot$ ACEM 


\section{Introduction}

Metabolic syndrome is a cluster of systemic disorders and is well known to increase the risk of endocrinopathy. Insulin resistance plays a central role and is related to the all components of metabolic syndrome, defined by the presence of central obesity, dyslipidemia, glucose intolerance or diabetes mellitus, and hypertension [1]. National Cholesterol Education Program's Adult Treatment Panel III (NCEP-ATP III) criteria and International Diabetes Federation (IDF) criteria are used for diagnosis of metabolic syndrome [2]. According to the ATP III criteria, metabolic syndrome is reported to be present in $30 \%$ of men and $41.8 \%$ of women in Turkey [3]. The same study also showed an increase in the prevalence of the metabolic syndrome, especially over the age of 45 years.

Osteoporosis is one of the most common diseases worldwide. Due to its prevalence, osteoporosis is considered as an important public health concern. Approximately $30 \%$ of all postmenopausal women have osteoporosis in the United States and in Europe [4]. Osteoporosis and cardiovascular disease are age-related conditions that affect mortality and morbidity. The relation of coronary artery atherosclerosis and calcification with osteoporosis is reported in women [5]. Atherosclerosis and hyperlipidemia were also reported to be associated with osteoporosis [6].

The data about the association between osteoporosis and the metabolic syndrome is limited [7,8]. There is no data in the literature, concerning the relation of postmenopausal osteoporosis and metabolic syndrome in Turkish population. Therefore, we aimed to probe the relation of osteoporosis and metabolic syndrome in postmenopausal women.

\section{Material and Methods}

The study was approved by Bozok University ethics committee. All procedures were in accordance with the ethical standards of the responsible committee on human experimentation (institutional and national) and with the Helsinki Declaration of 1975, as revised in 2008 and informed consent was obtained from all participants for being included in the study. Written consent could not be taken due to the retrospective design of the study.

A total of consecutive 98 postmenopausal women who were younger than 65 years living in Yozgat area/Turkey were enrolled in the study between January 2016 and January 2017. All participants were postmenapousal for at least one year. Patients suffering from ischemic heart disease, chronic systemic inflammatory disorders, patients with renal failure, patients suffering from thyroid and parathyroid related disorders and patients above 65 years of age were excluded from the study.

Participants were assigned in two groups based on their bone mineral density (BMD) score; 49 participants who had Tscore $>-2.5$ at the spine or/and femoral neck were included in the group without osteoporosis (Group 1) and 49 participants who had $\mathrm{T}$-score $\leq-2.5$ at the spine or/and femoral neck were included in the osteoporosis group (Group 2).

Personal medical history, including age and menopause duration was obtained. Weights $(\mathrm{kg})$ and heights $(\mathrm{m})$ of the participants were measured. Body mass index (BMI) as $\mathrm{kg} / \mathrm{m}^{2}$ was calculated by the formula of (weight in $\mathrm{kg}$ ) / (height in meters ${ }^{2}$ ). Waist circumference (WC) of the participants was measured to evaluate abdominal obesity. Blood pressure $(\mathrm{mmHg})$ was measured using with standard mercury manometer. The normal limit was $130 \mathrm{mmHg}$ for systolic blood pressure and $85 \mathrm{mmHg}$ for diastolic blood pressure, consistent with NCEPATP III cut points for blood pressure in the definition of the metabolic syndrome [2]. Patients taking antihypertensive medications were also classified as hypertensive. Blood samples for fasting glucose, serum calcium $(\mathrm{mg} / \mathrm{dL}), 25 \mathrm{OH}$ vitamin $\mathrm{D}$ $(\mathrm{ng} / \mathrm{mL})$ and lipid parameters including total cholesterol (mg/dL), HDL (mg/dL), LDL (mg/dL) and triglyceride $(\mathrm{mg} / \mathrm{dL})$ were centrifuged at room temperature for 5 minutes at 3000 RPM. The extracted serum was kept in ice bags and put in deep freezers at $-80^{\circ} \mathrm{C}$.

Metabolic syndrome was defined with the NCEP ATP III criteria. This definition requires the presence of at least three or more of the five components of the following categorically defined risk factors: Abdominal obesity; waist circumference greater than $88 \mathrm{~cm}$, hypertension $(130 / 85 \mathrm{mmHg}$ or greater, taking antihypertensive medications), high triglycerides (150 $\mathrm{mg} / \mathrm{dL}$ or greater), low HDL cholesterol (less than $50 \mathrm{mg} / \mathrm{dL}$ in women), hyperglycemia $(100 \mathrm{mg} / \mathrm{dL}$ or greater or taking antidiabetic medication) [2].

\section{Statistical analysis}

The findings were analyzed statistically using the Statistical Package for the Social Sciences, version 18.0 (Chicago, IL). The distribution was evaluated with the ShapiroWilk test. Continuous variables were expressed as mean \pm standard deviation and non-normally distributed variables were expressed as median with minimum and maximum values. Mean values of the two groups were compared by independent samples $\mathrm{T}$ test for variables distributed normally and Mann-Whitney Utest for variables distributed non-normally. Chi square test was used for categorical variables. The value of $p<0.05$ was considered statistically significant.

\section{Results}

Descriptive characteristics are summarized in Table. When compared with Group 1, mean age (54.5 \pm 5.7 vs. 58.2 \pm 4.6 ; $\mathrm{p}=0.001)$, menopausal duration $[7 \quad(1-20)$ vs. 10 (1-24); $\mathrm{p}=0.003)]$, systolic blood pressure $(121.1 \pm 10.9$ vs. $128.7 \pm 13.7$; $\mathrm{p}=0.004)$ and diastolic blood pressure $(76.7 \pm 7.8$ vs. $81.7 \pm 7.8$; $\mathrm{p}=0.001$ ) were significantly higher in Group 2. Lumbar spine BMD (-1.68 \pm 0.59 vs. $-3.03 \pm 0.49 ; \mathrm{p}=0.001)$ and femur neck BMD ( $-1.19 \pm 0.65$ vs. $-1.95 \pm 0.84 ; \mathrm{p}=0.001)$ were significantly lower in Group 2.

There were no significant difference between the groups in terms of menopause age $(\mathrm{p}=0.997)$, weight $(\mathrm{p}=0.324)$, height $(\mathrm{p}=0.388)$, BMI $(\mathrm{p}=0.541)$, fasting glucose $(\mathrm{p}=0.539)$, total cholesterol $(p=0.628)$, HDL $\quad(p=0.444)$, LDL $\quad(p=0.732)$, triglyceride $(\mathrm{p}=0.198)$, and serum $25 \mathrm{OH}$ vitamin $\mathrm{D}(\mathrm{p}=0.707)$ levels (Table).

The prevalence of the metabolic syndrome was $62 \%$ (61 of 98 participants) in all study population. The metabolic syndrome was detected in $25(51 \%)$ of 49 participants and 36 $(73 \%)$ of 49 participants in Group 1 and Group 2, respectively. 
There was a statistically significant relationship between osteoporosis and the metabolic syndrome $(\mathrm{p}=0.037)$.

Table: Descriptive features

\begin{tabular}{|c|c|c|c|}
\hline Parameter & $\begin{array}{c}\text { Group } 1 \\
(\mathrm{n}=49)\end{array}$ & $\begin{array}{c}\text { Group } 2 \\
(\mathrm{n}=49)\end{array}$ & $\mathrm{p}$ \\
\hline Age $\left(\right.$ year) ${ }^{\beta}$ & $54.5 \pm 5.7$ & $58.2 \pm 4.6$ & 0.001 \\
\hline Height $(m)^{\beta}$ & $1.56 \pm 0.06$ & $1.55 \pm 0.05$ & 0.388 \\
\hline Weight $(\mathrm{kg})^{\beta}$ & $80.4 \pm 12.1$ & $78.0 \pm 12.6$ & 0.324 \\
\hline Body mass index $\left(\mathrm{kg} / \mathrm{m}^{2}\right)^{\beta}$ & $32.9 \pm 5.3$ & $32.2 \pm 5.5$ & 0.541 \\
\hline Waist circumference $(\mathrm{cm})^{\beta}$ & $103.4 \pm 12.3$ & $104.8 \pm 10.6$ & 0.523 \\
\hline Lumbal spine BMD $\left(\mathrm{g} / \mathrm{cm}^{2}\right)^{\beta}$ & $-1.68 \pm 0.59$ & $-3.03 \pm 0.49$ & 0.001 \\
\hline Femur neck BMD $\left(\mathrm{g} / \mathrm{cm}^{2}\right)^{\beta}$ & $-1.19 \pm 0.65$ & $-1.95 \pm 0.84$ & 0.001 \\
\hline Menopause age (year) ${ }^{\beta}$ & $47.3 \pm 6.2$ & $47.9 \pm 3.9$ & 0.997 \\
\hline Menopausal duration (year) $^{\mu}$ & $7(1-20)$ & $10(1-24)$ & 0.003 \\
\hline Fasting glucose $(\mathrm{mg} / \mathrm{dL})^{\mu}$ & $\begin{array}{c}101(71- \\
310)\end{array}$ & $\begin{array}{c}109(73- \\
301)\end{array}$ & 0.539 \\
\hline Total cholesterol $(\mathrm{mg} / \mathrm{dL})^{\beta}$ & $203.7 \pm 35.6$ & $207.6 \pm 42.4$ & 0.628 \\
\hline $\operatorname{HDL}(\mathrm{mg} / \mathrm{dL})^{\beta}$ & $51.0 \pm 10.6$ & $52.8 \pm 11.0$ & 0.444 \\
\hline $\operatorname{LDL}(\mathrm{mg} / \mathrm{dL})^{\beta}$ & $123.4 \pm 30.7$ & $125.7 \pm 33.4$ & 0.732 \\
\hline Triglyceride $(\mathrm{mg} / \mathrm{dL})^{\beta}$ & $127(39-427)$ & $\begin{array}{c}143(57- \\
451)\end{array}$ & 0.198 \\
\hline Serum c & $9.5 \pm 0.5$ & $9.5 \pm 0.4$ & 0.824 \\
\hline $25 \mathrm{OH}$ vitamin $\mathrm{D}(\mathrm{ng} / \mathrm{mL})^{\mu}$ & $14(4-68)$ & $14(4.1-134)$ & 0.707 \\
\hline $\begin{array}{l}\text { Mean sistolic pressure } \\
(\mathrm{mm} / \mathrm{Hg})^{\beta}\end{array}$ & $121.1 \pm 10.9$ & $128.7 \pm 13.7$ & 0.004 \\
\hline $\begin{array}{l}\text { Mean diastolic pressure } \\
(\mathrm{mm} / \mathrm{Hg})^{\beta}\end{array}$ & $76.7 \pm 7.8$ & $81.7 \pm 7.8$ & 0.001 \\
\hline Metabolic syndrome (n (\%)) & $25(51 \%)$ & $36(\% 73)$ & 0.037 \\
\hline
\end{tabular}

$\beta$ : mean \pm standard deviation, $\mu$ : median and range

\section{Discussion}

In this study, a significant relation has been found between metabolic syndrome and osteoporosis in postmenopausal women.

Obesity is commonly seen in postmenopausal women. Silva et al. reported that about $50 \%$ of postmenopausal women are obese [9]. Previous studies have demonstrated that body fat mass and BMI were higher in postmenopausal women than perimenopausal women [10]. In this study, mean BMI in both groups were above $30 \mathrm{~kg} / \mathrm{m} 2$ as obese. However, there were no significant differences in BMI, WC and weight between the groups.

A several number of studies have supported that osteoporosis and cardiovascular diseases have a link because of common pathophysiological and genetic risk factors [11-13]. Recent studies also proved that estrogen deficiency is an independent risk factor for osteoporosis and coronary heart disease $[12,13]$. Estrogen level has been found to be positively correlated with BMD and HDL [14, 15]. Barengolts et al. compared the lipid profile in postmenopausal women with and without osteoporosis [16]. No significant difference was found between the groups. Same as the literature, in our study, there was no significant difference in lipid profiles in postmenopausal women with and without osteoporosis. On the other hand, the prevalence of both cardiovascular disease and osteoporosis increase with advanced age [17]. All postmenopausal patients included the study were under 65 years of age, because the risk of cardiovascular disease was expected to increase with age progression, especially above 60 .

The components of metabolic syndrome, such as high blood pressure, increased triglycerides, and reduced HDL are also related to osteoporosis while other components such as obesity are not. It is demonstrated that osteoporosis is related to inflammation. It was recently shown that, participants with high insulin resistance have more inflammation than participants with low insulin resistance $[18,19]$. Some studies advocated that low chronic inflammation may affect bone health [20]. According to a study, the prevalence of DM and insulin resistance in postmenopausal women was higher than in premenopausal women [21]. Gundoğan et al. reported that women who were between 50-59 ages had higher prevalence of the metabolic syndrome than normal population [3]. They found the metabolic syndrome rate as $40.4 \%$, according to NCEP-ATP III criteria and as $48.3 \%$ according to IDF criteria. The impact of risk factors of the metabolic syndrome on bone health has been regarded as controversial in the literature [22-24].

A study showed that there was an association between metabolic syndrome features and prevalent osteoporotic fractures in a cross-sectional analysis, and metabolic syndrome was related to lower BMD [24]. The opposite results have also been reported [22, 23]. Especially in some studies, the authors suggested that obesity, diabetes and the metabolic syndrome have protective effects for osteoporosis [22]. On the other hand, a meta-analysis indicated that the metabolic syndrome is associated with a $15 \%$ reduced risk of fractures in adults [23].

In the present study, the rate of the metabolic syndrome was higher in patients with osteoporosis. Also mean systolic and diastolic blood pressures were higher in patients with postmenopausal osteoporosis. Sedentary lifestyle can potentially contribute to insufficient sun exposure and individual components of metabolic syndrome. Age of the patients with postmenopausal osteoporosis was significantly higher than the patients without postmenopausal osteoporosis. Therefore, we thought that significant differences in the prevalence of the metabolic syndrome between the groups may be related to higher age, and also sedentary lifestyle in the postmenopausal osteoporosis group.

Our study has several limitations; because of crosssectional study design, we cannot assess reasons between metabolic syndrome and low BMD. Secondly, our group consists of female patients who refer to the endocrine clinic. Population generalization cannot be done because it does not include male patients.

In conclusion, in our study, the prevalence of the metabolic syndrome was found to be higher as $62 \%$ in all the postmenopausal participants. Our result showed that rate of the metabolic syndrome was higher in patients with osteoporosis than the patients without osteoporosis in the postmenopausal patients under 65 years of age.

\section{References}

1. Isomaa B. A major health hazard: the metabolic syndrome. Life Sci. 2003;73:2395-411.

2. Lorenzo C, Williams K, Hunt KJ, Haffner SM. The National Cholesterol Education Program-Adult Treatment Panel III, International Diabetes Federation, and World Health Organization definitions of the metabolic syndrome as predictors of incident cardiovascular disease and diabetes. Diabetes Care. 2007;30:8-13.

3. Gundogan K, Bayram F, Gedik V, Kaya A, Karaman A, Demir O, et al. Metabolic syndrome prevalence according to ATP III and IDF criteria and related factors in Turkish adults. Arch Med Sci. 2013;9:243. 
4. Melton III LJ, Chrischilles EA, Cooper C, Lane AW, Riggs BL. Perspective how many women have osteoporosis? J Bone Miner Res. 1992;7:1005-10.

5. Sprini D, Rini GB, Di Stefano L, Cianferotti L, Napoli N. Correlation between osteoporosis and cardiovascular disease. Clin Cases Miner Bone Met. 2014;11:117.

6. Tintut Y, Morony S, Demer LL. Hyperlipidemia promotes osteoclastic potential of bone marrow cells ex vivo. Arterioscler Thromb Vasc Biol. 2004;24:e6-e10.

7. Jankowska E, Rogucka E, Mędraś M. Are general obesity and visceral adiposity in men linked to reduced bone mineral content resulting from normal ageing? A population-based study. Andrologia. 2001;33:384-9.

8. Blaauw R, Albertse EC, Hough S. Body fat distribution as a risk factor for osteoporosis. South Afr Med J. 1996;86(9).

9. Silva HG, Mendonça L, Conceição FL, Zahar SE, Farias MLF. Influence of obesity on bone density in postmenopausal women. Arq Bras Endocrinol Metabol. 2007;51:943-9.

10. Lindsay R, Cosman F, Herrington BS, Himmelstein S. Bone mass and body composition in normal women. J Bone Miner Res. 1992;7:55-63.

11. Anagnostis P, Karagiannis A, Kakafika AI, Tziomalos K, Athyros VG, Mikhailidis DP. Atherosclerosis and osteoporosis: age-dependent degenerative processes or related entities? Osteoporosis international : a journal established as result of cooperation between the European Foundation for Osteoporosis and the National Osteoporosis Foundation of the USA. Osteopoprs Int. 2009;20:197-207.

12. McFarlane SI, Muniyappa R, Shin JJ, Bahtiyar G, Sowers JR. Osteoporosis and cardiovascular disease: brittle bones and boned arteries, is there a link? Endocrine. 2004;23:1-10.

13. Divers J, Register TC, Langefeld CD, Wagenknecht LE, Bowden DW, Carr JJ, et al. Relationships between calcified atherosclerotic plaque and bone mineral density in African Americans with type 2 diabetes. J Bone Miner Res. 2011;26:1554-60.

14. Cummings S. Factors associated with appendicular bone mass in older women. Ann Intern Med. 1993;118:657-65.

15. Grady D, Rubin SM, Petitti DB, Fox CS, Black D, Ettinger B, et al. Hormone therapy to prevent disease and prolong life in postmenopausal women. Ann Int Med. 1992;117:1016-37.

16. Barengolts EI, Berman M, Kukreja SC, Kouznetsova T, Lin C, Chomka EV. Osteoporosis and coronary atherosclerosis in asymptomatic postmenopausal women. Calcif Tissue Int. 1998;62:209-13.

17. Banks L, Lees B, MacSweeney J, Stevenson J. Effect of degenerative spinal and aortic calcification on bone density measurements in postmenopausal women: links between osteoporosis and cardiovascular disease? Eur J Clin Invest. 1994;24:813-7.

18. Esser N, Legrand-Poels S, Piette J, Scheen AJ, Paquot N. Inflammation as a link between obesity, metabolic syndrome and type 2 diabetes. Diabetes Res Clin Pract. 2014;105:141-50.

19. Romeo GR, Lee J, Shoelson SE. Metabolic syndrome, insulin resistance, and roles of inflammation-mechanisms and therapeutic targets. Arterioscler Thromb Vasc Biol. 2012;32:1771-6.

20. Ginaldi L, Di Benedetto MC, De Martinis M. Osteoporosis, inflammation and ageing. Immun Ageing. 2005;2:14.

21. Kaya A, Turan E, Uyar M, Bayram F, Turan Y. The Prevalence of Insulin Resistance in the Turkish Population: A Study Conducted with 3331 Participants. EJMO. 2017;1:202-6. DOI: 10.14744/ejmo.2017.02886

22. Hernández J, Olmos J, González-Macías J. Metabolic syndrome, fractures and gender. Maturitas. 2011;68:217-23.

23. Esposito K, Chiodini P, Capuano A, Colao A, Giugliano D. Fracture risk and bone mineral density in metabolic syndrome: a meta-analysis. J Clin Endocrinol Metab. 2013;98:3306-14.

24. Von Muhlen D, Safii S, Jassal S, Svartberg J, Barrett-Connor E. Associations between the metabolic syndrome and bone health in older men and women: the Rancho Bernardo Study. Osteoporos Int. 2007;18:1337-44. 